\title{
The System Dynamics Model in Electronic Products Closed-Loop Supply Chain Distribution Network with Three-Way Recovery and the Old-for-New Policy
}

\author{
Xiao-qing Zhang and Xi-gang Yuan \\ The School of Statistics, Southwestern University of Finance and Economics, Chengdu 611130, China \\ Correspondence should be addressed to Xi-gang Yuan; 114120100001@2014.swufe.edu.cn
}

Received 25 December 2015; Accepted 3 March 2016

Academic Editor: Paolo Renna

Copyright (C) 2016 X.-q. Zhang and X.-g. Yuan. This is an open access article distributed under the Creative Commons Attribution License, which permits unrestricted use, distribution, and reproduction in any medium, provided the original work is properly cited.

\begin{abstract}
With the technological developments and rapid changes in demand pattern, diverse varieties of electronic products are entering into the market with reduced lifecycle which leads to the environmental problems. The awareness of electronic products takeback and recovery has been increasing in electronic products supply chains. In this paper, we build a system dynamics model for electronic products closed-loop supply chain distribution network with the old-for-new policy and three electronic products recovery ways, namely, electronic products remanufacturing, electronic component reuse and remanufacturing, and electronic raw material recovery. In the simulation study, we investigate the significance of various factors including the old-for-new policy, collection and remanufacturing, their interactions and the type of their impact on bullwhip, and profitability through sensitivity analysis. Our results instruct that the old-for-new policy and three electronic products recovery ways can reduce the bullwhip effect in the retailers and the distributors and increases the profitability in the closed-loop supply chain distribution network.
\end{abstract}

\section{Introduction}

With science and technology rapid development, the number of electronic products is rapidly increasing, the update speed is quicker, and the lifestyle becomes shorter and shorter. This phenomenon can result in the electronic products' recovery and reuse problem. The regulation of recycling and disposal of waste electronic products is proposed in 2004. The televisions, refrigerators, washing machines, air conditioning, and computer products are listed in the first five recycling product catalogues. Thus, not only considering the production, inventory and distribution problem, but also considering the old electronic products' recovery and reuse problem when the electronic products manufacturer make project.

On the problem of the old-for-new policy, many scholars have done a lot of works. Fleischmann et al. [1] provided a review of the quantitative models for reverse logistics in which they reported that most of the papers in the area of integrated reverse logistics are confined to single issues while comprehensive approaches are rare as variety of factors are involved in a general framework and the complexity of their interdependencies. De Brito and Dekker [2] presented a framework for RL in which they discussed the recovery process and driving forces behind product returns. Blackburn et al. [3] and Grubbström and Tang [4] dealt with recovery process but did not address the possibility of product recovery in three different ways. Guo and Jiang [5] built a decision model for discarded electronics considering three levels of recycling: product reuse, component reuse, and material reuse. Ferguson and Toktay [6] developed a model to support a manufacturer's recovery strategy in the face of a competitive threat on the remanufactured product market. They analyzed the competition between new and remanufactured products produced by a monopolist manufacturer and identified conditions under which the firm would choose not to remanufacture its products. Pagell et al. [7] pointed out that product remanufacturing was the most desirable option for endof-life-product management compared to a scrap or spares recovery since it minimized the environmental impacts, 
resulted in lower loss of value, and could create new market opportunities. Vlachos et al. [8] tackled the development of efficient capacity planning policies for remanufacturing facilities in reverse supply chains, taking into account not only economic but also environmental issues, such as the take-back obligation imposed by legislation and the "green image" effect on customer demand. Atasu et al. [9] provided an alternative and complementary approach that considered further issues such as the existence of green segments, OEM competition, and product life cycle effects. Gallo et al. [10] analyzed the secondary markets opportunities for hybrid remanufacturing/manufacturing systems.

Geyer and Blass [11] examined the economics of cell phone reuse and recycling based on detailed primary data collected from reverse logistics and reuse and recycling operations in 2003 in the UK and in 2006 in the US. They show that while cell phone reuse has a healthy profit margin, and handset recycling is currently a byproduct of reuse. Ferrer and Swaminathan [12] studied a firm that made new products in the first period and used returned cores to make remanufactured products (along with new products) in future periods. Georgiadis and Besiou [13] investigated the significance of the factors that comprised the environmental sustainability strategies (environmental legislation and green image) and the operational features of the closed-loop supply chain (CLSC) (chain's features, products' features, and economic parameters). Pati et al. [14] developed an analytical expression for measuring the bullwhip effect in a six-echelon closed-loop supply chain. Rogers et al. [15] pointed out that secondary market can provide a place for unwanted items to be bought and sold, reducing the products' ecological impact and creating economic value.

Junior and Filho [16] built a production planning and control for remanufacturing and a review of the quantitative models for RL by Fleischmann et al. [1] reports that most of the papers in the area of RL are confined to single issues such as network design, shop-floor control, and inventory control. Das and Dutta [17] developed a simulation model based on system dynamics to analyze the long-term behavior of a multi-forward-reverse supply chain with fuzzy demand. Wei and Zhao [18] come up with the pricing decision problem of a fuzzy closed-loop supply chain with retail competition.

To our knowledge, on the problem of the old-for-new policy in closed-loop supply chain, the research objects are the two or multiple-level closed-loop supply chains consisting of one manufacturer and one retailer or multiple manufacturers and multiple retailers. On the contrary, in this paper, we consider a SD model for an electronic products closed-loop supply chain distribution network which includes one-electronic-product manufacturer, twoelectronic-product distributor, and two-electronic-product retailer. We assumed that the remanufacturing process can bring back the used electronic products into an "as good as new" condition and the remanufactured electronic products can be redistributed in primary market to satisfy the demands of the customers. What is more, we come up with three electronic products recovery ways, namely: electronic products remanufacturing, electronic component reuse and remanufacturing and electronic raw material recovery and add the-old-for-new-policy to the electronic products closedloop supply chain distribution network. At last, we design an experiment to examine the impact of various parameters of the electronic products supply chain distribution network model on bullwhip effect and profit (Figure 6). At the same time, we investigate the significance of various factors including the old-for-new policy, collection and remanufacturing, their interactions and the type of their impact on bullwhip, and profitability through sensitivity analysis and variance analysis.

The rest of this paper is organized as follows. Section 2 provides the problem description. Section 3 builds the electrical closed-loop supply chain distribution network system dynamics model. Section 4 discusses the result. Section 5 discusses sensitivity analysis and variance analysis. The final section is conclusion that outlines the limitations of this paper and directions for future research.

\section{Problem Description}

In China, most of the electronic products companies mainly focus on managing the forward supply chain and pay no attention to recycling the old electronic products which leads to the extension of time, the backlog of inventory, and the decrease of profit. Depending on the electronic product's value, manufacturer has a variety of options to maximize the value of returned electronic products through multiple liquidation channels. For the purpose of this study, we design three scenes in the paper.

2.1. Scene One: Electronic Products Remanufacturing. Most of the time, the remanufacturing of the old electronic products is, respectively, for the producing of the traditional electronic products. After break-up, the old electronic products can be new electronic products and they can satisfy the costumer's demand (Östlin et al. [19]; Wei and Zhao [18]). In this way, the traditional electrical supply chain distribution network can become a closed-loop supply chain distribution network.

\subsection{Scene Two: Electronic Component Reuse and Reman-} ufacturing. Sometimes, because of the quality of the old electronic products, it cannot enter into the primary market. So the secondary market plays a very important role. It can create new economic value and reduce environmental pollution (Rogers et al. [15]). In this way, the electronic products supply chain distribution network can become an open-loop supply chain distribution network.

\subsection{Scene Three: Electronic Raw Material Recovery. Some} of the waste electronic products have no value directly discarded, due to the environmental protection and legal requirements. Manufacturer should pay attention to the processing of waste electronic products. This research mainly studies the electronic product recovery, the forward supply chain distribution network is mainly composed of one-electronic-products supplier, one-electronic-product manufacturer, two-electronic-product distributor, and twoelectronic-product retailer. The reverse supply chain mainly 


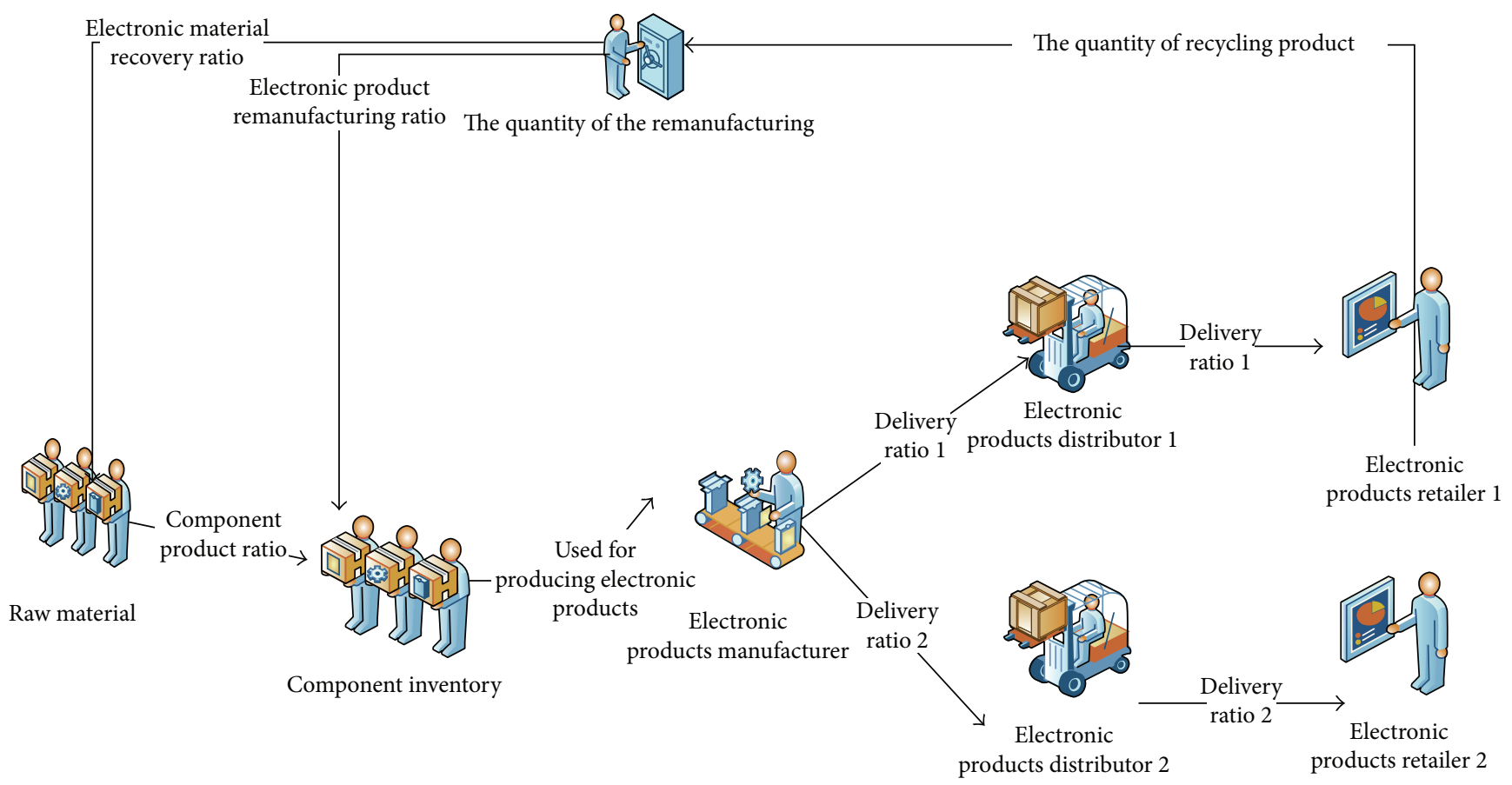

FIGURE 1: The electronic products closed-loop supply chain distribution network system conceptual model.

includes electronic products' recovery and electronic components' recovery and electronic raw materials' recycling.

\section{The Electronic Products Closed-Loop Supply Chain Distribution Network System Dynamics Model}

3.1. The Electronic Products Closed-Loop Supply Chain Distribution Network System Dynamics Flow Chart. System dynamics (SD) is a kind of tools used for modeling and simulation, and the system flow chart is used to describe the relationship between elements. The system dynamics model mainly includes statement variable, rate variable, and level variable. Based on above instruction, the electronic products closed-loop supply chain distribution network system conceptual model and flow chart are shown in Figures 1 and 2, respectively.

According to system dynamics flow chart (Figure 2), we want to instruct the operation process of the electronic products closed-loop supply chain.

3.1.1. The Forward Electronic Products Closed-Loop Supply Chain. The forward electronic products closed-loop supply chain can include several parts: raw material, component inventory, manufacturer inventory, distributor inventory, and retailer inventory. Manufacturer's demand for raw materials determines the inventory of raw materials. The inventory of component depends on component productivity, component ratio used for producing electronic product, and component remanufacturing ratio. Component ratio used for producing electronic product depends on the producing time, the expect order, the difference of the manufacturers' inventory, and manufacturers' inventory adjustment time. Electronic products productivity depends on component ratio used for produce electronic product. Manufacturers' inventory depends on products produce ratio, the delivery ratio to distributor, and remanufacturing ratio 1 . The delivery ratio to distributor depends on the delivery time, the backlog orders of distributor, the distributors' order, and manufacturers' inventory. Distributors' inventory depends on the delivery ratio to distributor and the delivery ratio to retailer. The delivery ratio to retailer depends on the delivery time, distributors' inventory, and the backlog orders of retailer. Retailer inventory depends on the delivery ratio to retailer and electronic products market sales' ratio.

3.1.2. The Reverse Electronic Products Closed-Loop Supply Chain. The reverse electronic products closed-loop supply chain can include electronic products recovery, component recovery, and raw material recovery and remanufacturing. The electronic products recovery can include inspection, sorting, disassembly, and assembly. The recovery electronic products should be inspected; some of them can be used for making new products, and some of them can be used for making old products. The quantity of recycling product depends on remanufacturing ratio, and electrical product can be remanufacturing rate. The quantity of the electrical remanufacturing depends on remanufacturing ratio. The old component can be divided into directly remanufacturing component and need processing component. Directly remanufacturing component can be recovered and reused directly, and need processing component should be processed and recovered. The component which cannot be processed should be recovered as raw material. The variable in recovery process 


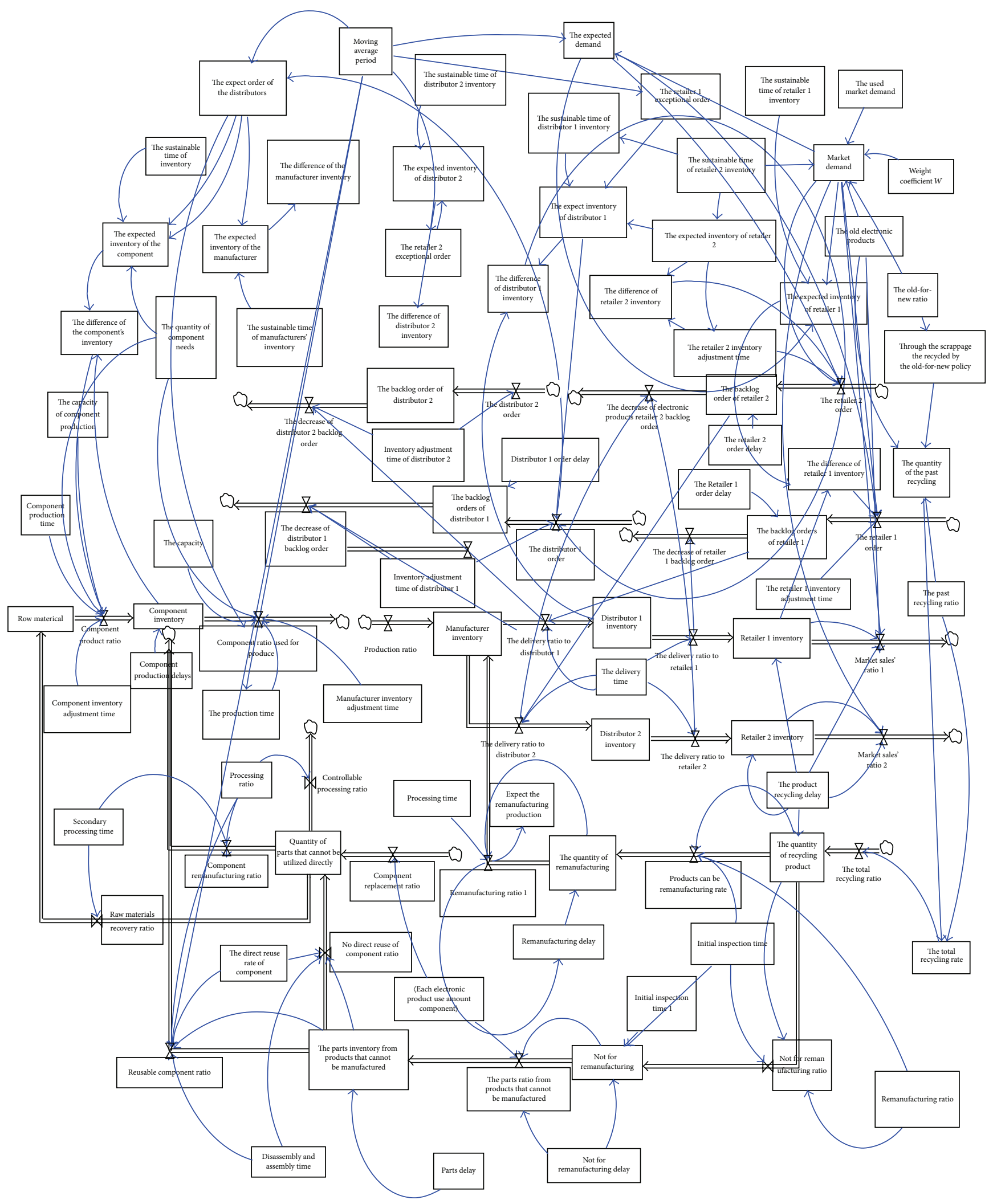

FIGURE 2: The electronic products closed-loop supply chain distribution network system dynamics flow chart. 
TABLE 1: Main parameters.

\begin{tabular}{|c|c|c|c|}
\hline Parameters & Time & Parameters & Time \\
\hline Dynamics weeks & 600 weeks & Component production time & 1.5 weeks \\
\hline Component production capacities & 800 units/week & Sustainable time of component inventory & 1.5 weeks \\
\hline Material production delay & 1 week & The capacity & 850 units/week \\
\hline Production time & 1.5 weeks & Moving average period & 1 week \\
\hline The exchange rate & $20 \%$ & Adjustment time of component inventory & 2 weeks \\
\hline Coefficient weight & 0.8 & Production delays & 1 week \\
\hline The delivery delay & 1.5 weeks & Transportation delay & 1 week \\
\hline Order delay of distributor 1 & 1 week & Order delay of distributor 2 & 1 week \\
\hline Processing ratio & $10 \%$ & Retailer 1 order delay & 1 week \\
\hline The old recovery ratio & $15 \%$ & Quantity of per electronic products & 6 weeks \\
\hline Component direct reuse ratio & $45 \%$ & Delay time & 40 weeks \\
\hline Retailer 2 order delay & 1 week & Component remanufacturing rate & $45 \%$ \\
\hline Sustainable time of the manufacturer's inventory & 1.5 weeks & Inventory adjustment time of manufacturers & 2 weeks \\
\hline Retailer 1 inventory adjustment time & 2 weeks & Adjustment time of distributor 1 inventory & 2 weeks \\
\hline Adjustment time of distributor 2 inventory & 2 weeks & Retailer 2 inventory adjustment time & 2 weeks \\
\hline Remanufacturing proportion & $50 \%$ & & \\
\hline
\end{tabular}

of component and raw material includes parts replacement ratio and electronic component remanufacturing ratio. Parts replacement ratio depends on remanufacturing ratio and component replacement ratio. The parts ratio which cannot be used for remanufacturing depends on the parts' remanufacturing ratio and other variables. Electronic component remanufacturing ratio depends on no direct reuse of component ratio, secondary processing time, disassembly and assembly time, and component remanufacturing ratio.

3.2. Parameters Setting. In order to analyze the relationship between the parameters, we set some parameters in system model (Table 1).

\section{Results and Discussion}

4.1. The Old-for-New Policy Impacts on Demand and Recovery. In this part, we establish the electronic products closedloop supply chain distribution network by Vensim software. System dynamics equations are as follows:

The recycled electronic products through the oldfor-new policy $=$ (the old-for-new rat) $\times$ (used in electronic products);

Quantity of the past recycling = (used in electronic products-the recycled electronic products through the-old-for-new-policy) $\times$ (the component recovery ratio);

The total recovery ratio $=$ (recycling electronic products through the-old-for-new-policy) + (the component recovery ratio);

Market demand $=$ (the past market demand) + (weight coefficient) $\times($ the-old-for-new-ratio $) \times$ (used electronic products).
The old-for-new ratio in electronic products belongs to $(0,1)$, and the past recycling ratio refers to the used electronic products without the old-for-new ways and proportion within $(0,1)$. Weight coefficient defined the relationship between the old-for-new policy and electronic products market demand. The fact that the weight coefficient is equal to zero refers to the fact that old-for-new policy has no effect on demand. The fact that the weight coefficient is greater than zero refers to the fact that the old-for-new policy has effect on demand.

By setting parameter and running the electronic products closed-loop supply chain distribution network system model, we can know that the old-for-new policy impacts the market demand and the total quantity of recycling. We can see from Figure 3, with the increasing of the old-for-new ratio, that the total quantity of recycling can be increasing. We can see from Table 2, with the increasing of the old-for-new ratio and the weight coefficient, that the mean and the variance of the market demand are increasing.

4.2. The Old-for-New Policy Impacts on Bullwhip Effect. There is an important problem existing in the supply chain management that the information can be magnified and distorted in the process of upstream transmission. It refers to the "bullwhip effect." The ratio is between order variance and needs variance. Because, the use of electronic products on the market is uncertain, the recycling of the electronic products can be uncertain. It cannot be avoided.

We simulate retailers and distributors change of demands and orders in electronic products closed-loop supply chain distribution network. We calculate the bullwhip effect, and the parameters are at the same as the front.

We can see, from Figure 4 and Table 3, with the increasing of the old-for-new ratio, that the bullwhip effect in retailers 1 and 2 and distributors 1 and 2 is decreased, because with the 
TABLE 2: The old-for-new policy impact on market demand.

\begin{tabular}{lcccccc}
\hline \multirow{2}{*}{ The old-for-new ratio (\%) } & \multicolumn{3}{c}{ Market demand } \\
& Weight coefficient is 0 & \multicolumn{2}{c}{ Weight coefficient is 0.5 } & \multicolumn{2}{c}{ Weight coefficient is 1 } \\
& Mean & Variance & Mean & Variance & Mean & Variance \\
\hline 10 & 3506.54 & 1508.535 & 3506.54 & 1508.535 & 3506.54 & 1508.535 \\
30 & 3506.54 & 1508.535 & 4294.671 & 1609.177 & 5082.802 & 1822.154 \\
50 & 3506.54 & 1508.535 & 4820.091 & 1740.779 & 6133.642 & 2223.363 \\
70 & 3506.54 & 1508.535 & 5345.512 & 1912.202 & 7184.483 & 2703.296 \\
90 & 3506.54 & 1508.535 & 5870.932 & 2113.78 & 8235.323 & 3227.018 \\
100 & 3506.54 & 1508.535 & 6133.642 & 2223.363 & 8760.744 & 3499.225 \\
\hline
\end{tabular}

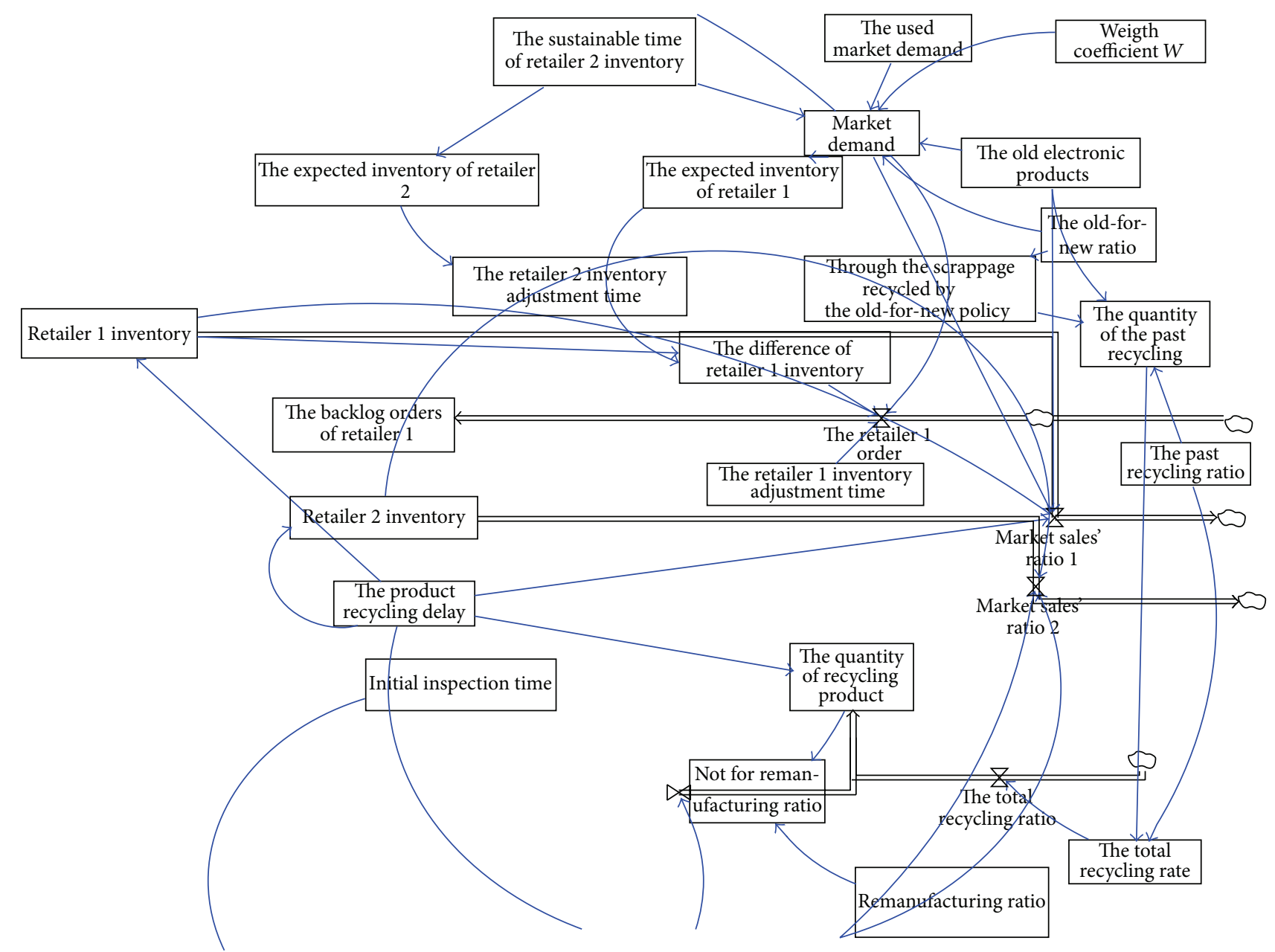

FIGURE 3: The old-for-new policy affects the system's variables.

increasing of the old-for-new ratio, the inventory difference is decreased in retailers 1 and 2 and distributors 1 and 2 .

4.3. The Old-for-New Policy Has Impact on the Profit. In order to illustrate how the old-for-new policy impacts profits, define the following profit formula:

Profit $=$ (recycling benefits - recycling cost $-R) \times$ (remanufacturing revenue $)+(1-R) \times($ recycling revenue $-R) \times($ remanufacturing cost $)-(1-R) \times$ (recycling cost) - (collection old electrical parts cost).

$R$ refers to the electronic products remanufacturing ratio. In order to analyze how the old-for-new policy impacts profits, we can get the result in Figure 5. With the increasing of the old-for-new ratio, the total profits are increasing in the electronic products closed-loop supply chain distribution network. Because the quantity of the recovery is difficult to determine in old electronic products, the electronic products 
TABLE 3: The old-for-new policy has influence on the profit.

\begin{tabular}{|c|c|c|c|c|c|c|}
\hline \multirow[b]{2}{*}{ The old-for-new ratio (\%) } & \multicolumn{2}{|c|}{ Weight coefficient $=0$} & \multicolumn{2}{|c|}{ Weight coefficient $=0.5$} & \multicolumn{2}{|c|}{ Weight coefficient $=1$} \\
\hline & $\begin{array}{l}\text { Profits with the } \\
\text { old-for-new policy }\end{array}$ & $\begin{array}{c}\text { Profits without } \\
\text { the old-for-new } \\
\text { policy }\end{array}$ & $\begin{array}{l}\text { Profits with the } \\
\text { old-for-new } \\
\text { policy }\end{array}$ & $\begin{array}{l}\text { Profits without } \\
\text { the old-for-new } \\
\text { policy }\end{array}$ & $\begin{array}{l}\text { Profits with the } \\
\text { old-for-new } \\
\text { policy }\end{array}$ & $\begin{array}{c}\text { Profits without } \\
\text { the old-for-new } \\
\text { policy }\end{array}$ \\
\hline 0 & 100 & 100 & 100 & 100 & 100 & 100 \\
\hline 20 & 532 & 406 & 603 & 452 & 673 & 513 \\
\hline 40 & 635 & 503 & 742 & 503 & 731 & 631 \\
\hline 60 & 741 & 642 & 841 & 613 & 903 & 741 \\
\hline 100 & 894 & 692 & 1034 & 852 & 1037 & 840 \\
\hline
\end{tabular}

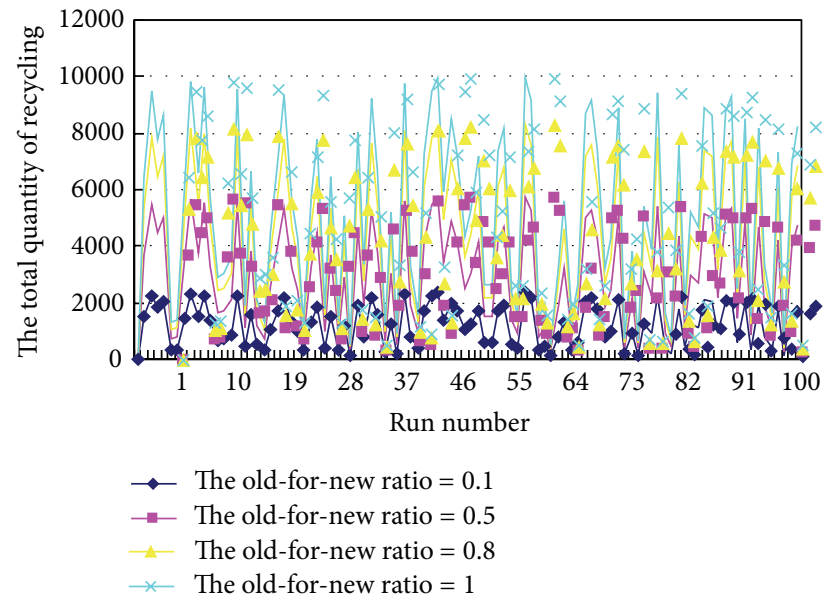

FIgURE 4: The old-for-new policy impact on quantity of recycling.

recyclers must find a suitable recycling ratio, which makes maximization profit as far as possible. Assuming the recycling rate is $50 \%$ in old electronic products, analyzing three different scenarios, we can get the charges of the profit in the electronic products supply chain distribution network ((1) the part recycling ratio is $50 \%$; (2) the old-for-new ratio is $25 \%$ and the part recycling ratio is $25 \%$; (3) the old-for-new ratio is $50 \%$ ).

If the old-for-new ratio is equal to zero, about $75 \%$ of the electronic products can be used for remanufacturing, recycling ratio can be increased, recycling cost can be decreased, and the profit can be increased. If the old-fornew ratio is $25 \%$, the normal recycling ratio is $25 \%$ and the remanufacturing ratio is more than $45 \%$; it can cause profit. If all the old electronic products can be recovered by the oldfor-new ways, the remanufacturing ratio is more than $25 \%$; it can cause profit. This shows that it can generate profits when the remanufacturing ratio is in a relatively low level, with enhancing recycling ratio for the old-for-new ways.

\section{Sensitivity Analysis of Electrical Products Closed-Loop Supply Chain}

Using sensitivity method in this section, analysis parameters impact the bullwhip effect and profit in electronic products closed-loop supply chain distribution network.

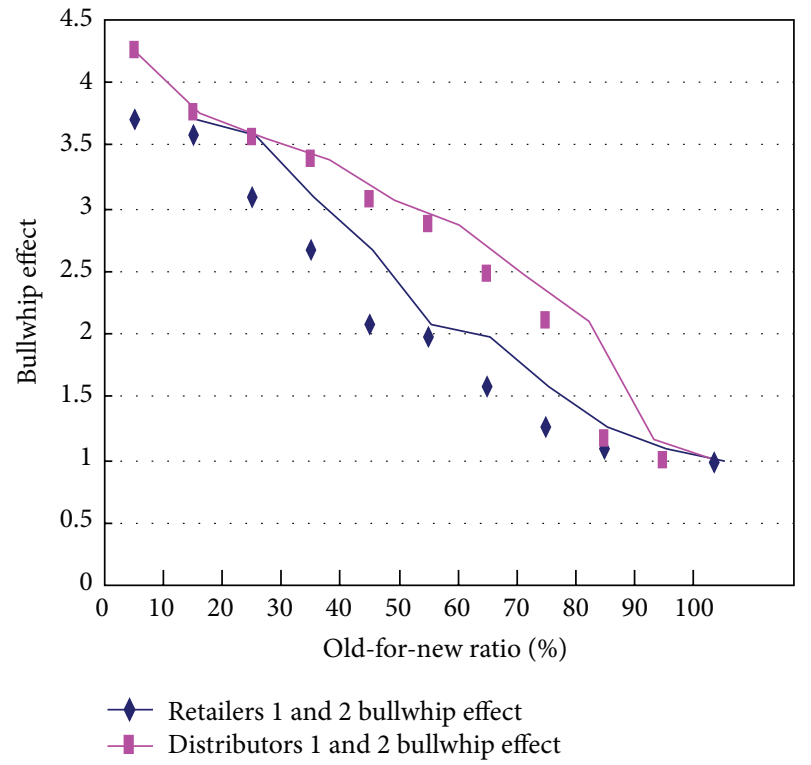

FIGURE 5: The old-for-new policy has influence on the bullwhip effect.

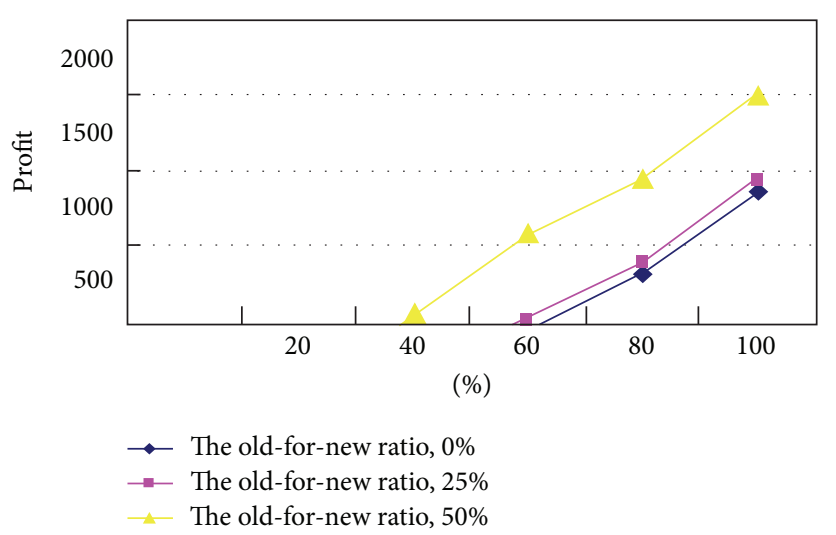

FIGURE 6: The old-for-new policy has impact on the profit.

5.1. Sensitivity Analysis in Electronic Products Closed-Loop Supply Chain Distribution Network. The first simulation time sets 1500 units, and we maintain that the inventory sustainable time and inventory adjustment time are constant, and other variables belong to $0 \%$ and $100 \%$. The second 
TABLE 4: Sensitivity analysis in electrical products closed-loop supply chain.

\begin{tabular}{|c|c|c|}
\hline Parameters & $\begin{array}{c}\text { Retailers } 1 \text { and } 2 \\
\text { bullwhip effect }\end{array}$ & $\begin{array}{c}\text { Distributors } 1 \text { and } \\
2 \text { bullwhip effect }\end{array}$ \\
\hline \multicolumn{3}{|c|}{ Inventory sustainable time and inventory adjustment time (constant) } \\
\hline The old-for-new ratio, remanufacturing ratio $\uparrow$ & $\downarrow$ & $\downarrow$ \\
\hline Recycling ratio (constant), remanufacturing ratio $\uparrow$ & $\downarrow$ & $\downarrow$ \\
\hline Remanufacturing ratio (constant), the old-for-new ratio $\uparrow$ & $\downarrow$ & $\downarrow$ \\
\hline Remanufacturing ratio (constant), recycling ratio $\uparrow$ & $\downarrow$ & $\downarrow$ \\
\hline The old-for-new ratio (constant), recycling ratio $\uparrow$ & $\downarrow$ & $\downarrow$ \\
\hline Recycling ratio (constant), the old-for-new ratio $\uparrow$ & $\downarrow$ & $\downarrow$ \\
\hline \multicolumn{3}{|l|}{$\begin{array}{l}\text { The old-for-new ratio (constant), recycling ratio (constant), } \\
\text { recycling ratio (constant) }\end{array}$} \\
\hline Retailer 1 inventory adjustment time $\uparrow$ & $\downarrow$ & $\downarrow$ \\
\hline Retailer 1 inventory sustainable time $\uparrow$ & $\downarrow$ & $\downarrow$ \\
\hline Distributor 1 inventory adjustment time $\uparrow$ & The same & The same \\
\hline Distributor 1 inventory sustainable time $\uparrow$ & The same & The same \\
\hline
\end{tabular}

simulation time sets 1500 unit, and we maintain inventory sustainable time and inventory adjustment time between 1 and 7 , with 1-week speed changing, and other variables are constant.

We can get the following conclusion from Table 4 .

From the first simulation result, we can see that the inventory sustainable time and inventory adjustment time are constant. (1) With the old-for-new ratio increasing, the bullwhip in retailers 1 and 2 and the bullwhip effect in distributors 1 and 2 are reduced; (2) remanufacturing ratio is constant, and with the old-for-new ratio and the recycling ratio increasing, the bullwhip in retailers 1 and 2 and the bullwhip effect in distributors 1 and 2 are reduced; (3) the recycling ratio is constant, and with electronic products remanufacturing increasing, the bullwhip in retailers 1 and 2 and the bullwhip effect in distributors 1 and 2 are reduced.

From the second simulation result, the old-for-new ratio, the recycling ratio, and remanufacturing ratio are constant. (1) With retailers 1 and 2 inventory sustainable time and retailers 1 and 2 inventory adjustment time increasing, the bullwhip in retailers 1 and 2 is reduced, and the bullwhip effects in distributors 1 and 2 are constant; (2) with distributors 1 and 2 inventory sustainable time and distributors 1 and 2 inventory adjustment time increasing, the bullwhip effect in distributors 1 and 2 is reduced, and the bullwhip in retailers 1 and 2 is constant.

5.2. Sensitivity Analysis of Profits in Electronic Products Closed-Loop Supply Chain Distribution Network. The electronic products remanufacturing ratio should be changed, and other variables are constants in the first simulation time; recycling ratio and products remanufacturing ratio should be changed, and other variables are constants in the second simulation time; the old-for-new ratio should be changed, and other variables are constants in the third simulation time. The result is in Table 5 .

We can see the following from Table 5: (1) when recycling ratio and remanufacturing ratio are constant, with the remanufacturing ratio increasing, the profit of the electronic products reverse supply chain distribution network is increasing; (2) when the old-for-new ratio is constant, with the remanufacturing ratio $(<30 \%)$ and the recycling ratio increasing, the profit of the electronic products reverse supply chain distribution network is decreasing; (3) when the old-for-new ratio is constant, with the remanufacturing ratio (>30\%) and recycling ratio increasing, the profit of the electronic products reverse supply chain distribution network is increasing; (4) when recycling ratio and remanufacturing ratio are constant, with the old-for-new ratio increasing, the profit of the electronic products reverse supply chain distribution network is increasing.

5.3. Variance Analysis. In this section, using variance analysis, we analyze the related parameters impact on the bullwhip effect and the profit in the electronic products closed-loop supply chain distribution network. System parameter values are shown in Table 6. We set up three different scenarios, running 6561 times.

We can get the following results from Table 6:

(1) The old-for-new ratio, recycling ratio, and remanufacturing ratio have more impact on the electronic products retailers 1 and 2 bullwhip effect, distributors 1 and 2 bullwhip effect, and the profit of the electronic products reverse supply chain distribution network. So, with the increasing of the old-for-new ratio, recycling ratio, and remanufacturing ratio, the bullwhip effect can be decreased and the profit of the electronic products reverse supply chain distribution network can be increased.

(2) (The old-for-new ratio) $\times$ (recycling ratio) has more impact on the electronic products retailers 1 and 2 bullwhip effect and distributors 1 and 2 bullwhip effect; however, it has no impact on the profit of the electronic products reverse supply chain distribution network. 
TABLE 5: The old-for-new ratio, remanufacturing ratio, and recycling ratio influence on the profits in supply chain.

\begin{tabular}{|c|c|c|c|}
\hline Parameters & $\begin{array}{l}\text { The profits of the } \\
\text { reverse supply } \\
\text { chain distribution } \\
\text { network }\end{array}$ & Parameters & $\begin{array}{l}\text { The profits of the } \\
\text { reverse supply chain } \\
\text { distribution network }\end{array}$ \\
\hline $\begin{array}{l}\text { The old-for-new ratio } \\
\text { (constant), recycling ratio } \\
\text { (constant) }\end{array}$ & & $\begin{array}{c}\text { Remanufacturing ratio } \%(>30 \%) \text {, } \\
\text { recycling ratio } \uparrow\end{array}$ & $\uparrow$ \\
\hline Remanufacturing ratio $\% \uparrow$ & $\uparrow$ & $\begin{array}{l}\text { Recycling ratio (constant), } \\
\text { remanufacturing ratio (constant) }\end{array}$ & \\
\hline $\begin{array}{l}\text { The old-for-new ratio } \\
\text { (constant) }\end{array}$ & & The old-for-new ratio $\uparrow$ & $\uparrow$ \\
\hline $\begin{array}{l}\text { Remanufacturing ratio\% } \\
(<30 \%) \text {, recycling ratio } \uparrow\end{array}$ & $\downarrow$ & & \\
\hline
\end{tabular}

TABLE 6: The results of variance analysis.

\begin{tabular}{|c|c|c|c|c|c|}
\hline Parameters & $\begin{array}{c}\text { Retailer } 1 \\
\text { bullwhip effect }\end{array}$ & $\begin{array}{c}\text { Retailer } 2 \\
\text { bullwhip effect }\end{array}$ & $\begin{array}{c}\text { Distributor } 1 \\
\text { bullwhip effect }\end{array}$ & $\begin{array}{c}\text { Distributor } 2 \\
\text { bullwhip effect }\end{array}$ & $\begin{array}{c}\text { Profit of reverse } \\
\text { supply chain } \\
\text { distribution } \\
\text { network }\end{array}$ \\
\hline Weight coefficient & 0.462 & 0.452 & 0.682 & 0.710 & $0.002^{*}$ \\
\hline The old-for-new ratio \% & 0.001 & $0.000^{*}$ & $0.000^{*}$ & $0.000^{*}$ & $0.000^{*}$ \\
\hline Recycling ratio \% & $0.000^{*}$ & $0.000^{*}$ & $0.000^{*}$ & $0.000^{*}$ & 0.864 \\
\hline Remanufacturing ratio \% & $0.000^{*}$ & $0.000^{*}$ & $0.000^{*}$ & $0.000^{*}$ & $0.000^{*}$ \\
\hline (The old-for-new ratio) $\times($ recycling ratio $)$ & $0.000^{*}$ & $0.000^{*}$ & $0.000^{*}$ & $0.000^{*}$ & 1.264 \\
\hline $\begin{array}{l}\text { (The old-for-new ratio }) \times(\text { remanufacturing } \\
\text { ratio) }\end{array}$ & $0.021^{*}$ & $0.002^{*}$ & 0.008 & 0.005 & $0.000^{*}$ \\
\hline$($ Recycling ratio $) \times($ remanufacturing ratio $)$ & 0.107 & 0.201 & 0.975 & 0.945 & $0.002^{*}$ \\
\hline (Weight coefficient $) \times($ the old-for-new ratio $)$ & $0.001^{*}$ & $0.000^{*}$ & $0.002^{*}$ & $0.001^{*}$ & $0.001^{*}$ \\
\hline $\begin{array}{l}\text { (Weight coefficient }) \times(\text { remanufacturing ratio }) \\
\times(\text { the old-for-new ratio })\end{array}$ & 0.963 & 0.893 & 0.962 & 0.843 & $0.000^{*}$ \\
\hline $\begin{array}{l}\text { (Weight coefficient }) \times(\text { recycling ratio }) \times(\text { the } \\
\text { old-for-new ratio })\end{array}$ & 0.752 & 0.798 & $0.000^{*}$ & $0.000^{*}$ & 0.664 \\
\hline
\end{tabular}

$p$ value $<0.026 . *$ refers to the minimum deviation value.

(3) (Remanufacturing ratio) $\times($ the old-for-new ratio) has no impact on retailers 1 and 2 bullwhip effect and distributors 1 and 2 bullwhip effect; however, it has more impact on the profit of the electronic products reverse supply chain distribution network, because by raising the electronic products remanufacturing ratio, we improve the utilization rate of the old electronic products, and this can reduce the electronic products manufacturing cost, so as to improve the profit of the electronic products reverse supply chain distribution network.

\section{Conclusions}

The old-for-new policy is introduced into the simulation model, thus, enhancing recycling efficiency, and we can see that, with improving the old-for-new ratio, the recycling ratio can be improved. With the increasing of the recovery ratio, the remanufacturing ratio, and the old-for-new ratio, retailers 1 and 2 bullwhip effect can be reduced and distributors 1 and 2 bullwhip effect can be reduced, too. With the improving of the old-for-new ratio, the profit of electronic products of reverse supply chain distribution network can be improved.

\section{Competing Interests}

The authors declare that they have no competing interests.

\section{Acknowledgments}

This work is supported by the Fundamental Research Funds for the Central Universities Project nos. JBK1607134 and JBK1507100.

\section{References}

[1] V. Fleischmann, R. Dekker, E. Van der Laan, J. Van Numen, L. Van Wassenhove, and J. Rowaard, "Quantitative models for reverse logistics," European Journal of Operational Research, vol. 103, pp. 1-17, 1997. 
[2] M. De Brito and R. Dekker, A System Dynamics Framework for an Integrated Forward-Reverse Supply Chain with Fuzzy Demand and Fuzzy Collection Rate Under Possibility Constraints, vol. 56, Springer, Berlin, Germany, 2004.

[3] J. Blackburn, V. Guide, G. Souza, and L. Van Wassenhove, "Reverse supply chain for commercial returns," California Management Review, vol. 46, pp. 6-22, 2004.

[4] R. W. Grubbström and O. Tang, "Optimal production opportunities in a remanufacturing system," International Journal of Production Research, vol. 44, no. 18-19, pp. 3953-3966, 2006.

[5] W. Guo and X. Jiang, "Green remanufacturing," in Proceedings of the 2nd International Eco-Electronics Conference, Beijing, China, December 2006.

[6] M. E. Ferguson and L. B. Toktay, "The effect of competition on recovery strategies," Production and Operations Management, vol. 15, no. 3, pp. 351-368, 2006.

[7] M. Pagell, Z. Wu, and N. N. Murthy, "The supply chain implications of recycling," Business Horizons, vol. 50, no. 2, pp. 133-143, 2007.

[8] D. Vlachos, P. Georgiadis, and E. Iakovou, "A system dynamics model for dynamic capacity planning of remanufacturing in closed-loop supply chains," Computers and Operations Research, vol. 34, no. 2, pp. 367-394, 2007.

[9] A. Atasu, M. Sarvary, and L. N. V. Wassenhove, "Remanufacturing as a marketing strategy," Management Science, vol. 54, no. 10, pp. 1731-1746, 2008.

[10] M. Gallo, L. Guerra, and G. Guizzi, "Hybrid remanufacturing/manufacturing systems: secondary markets issues and opportunities," WSEAS Transactions on Business and Economics, vol. 6, no. 1, pp. 31-41, 2009.

[11] R. Geyer and V. D. Blass, "The economics of cell phone reuse and recycling," International Journal of Advanced Manufacturing Technology, vol. 47, no. 5-8, pp. 515-525, 2010.

[12] G. Ferrer and J. M. Swaminathan, "Managing new and differentiated remanufactured products," European Journal of Operational Research, vol. 203, no. 2, pp. 370-379, 2010.

[13] P. Georgiadis and M. Besiou, "Environmental and economical sustainability of WEEE closed-loop supply chains with recycling: a system dynamics analysis," The International Journal of Advanced Manufacturing Technology, vol. 47, no. 5, pp. 475-493, 2010.

[14] R. K. Pati, P. Vrat, and P. Kumar, "Quantifying bullwhip effect in a closed loop supply chain," OPSEARCH, vol. 47, no. 4, pp. 231-253, 2010.

[15] D. S. Rogers, Z. S. Rogers, and R. Lembke, "Creating value through product stewardship and take-back," Sustainability Accounting, Management and Policy Journal, vol. 1, no. 2, pp. 133-160, 2010.

[16] M. Junior and M. Filho, "Production planning and control for remanufacturing: literature review and analysis," Production Planning and Control: The Management of Operations, vol. 23, no. 6, pp. 419-435, 2012.

[17] D. Das and P. Dutta, "A system dynamics framework for an integrated forward-reverse supply chain with fuzzy demand and fuzzy collection rate under possibility constraints," in Proceedings of the International Multi-Conference of Engineers and Computer Scientists, vol. 55, pp. 1592-1597, Hong Kong, March 2012.

[18] J. Wei and J. Zhao, "Pricing decisions with retail competition in a fuzzy closed-loop supply chain," Expert Systems with Applications, vol. 38, no. 9, pp. 11209-11216, 2011.
[19] J. Östlin, E. Sundin, and M. Björkman, "Importance of closedloop supply chain relationships for product remanufacturing," International Journal of Production Economics, vol. 115, no. 2, pp. 336-348, 2008. 


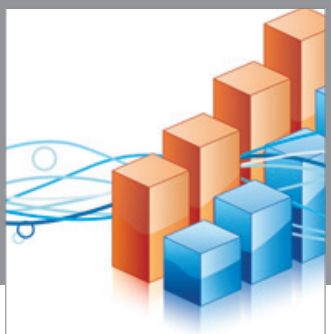

Advances in

Operations Research

vatem alat4

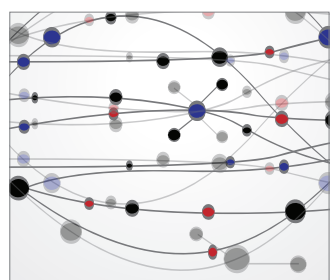

\section{The Scientific} World Journal
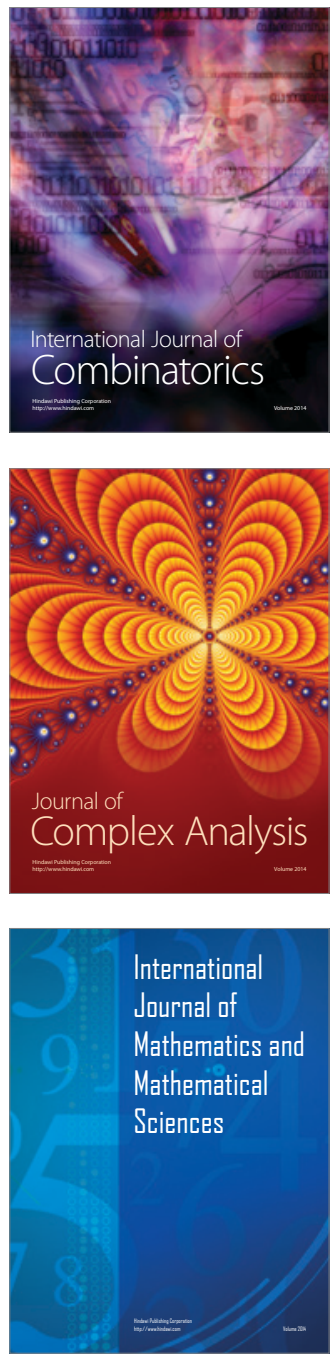
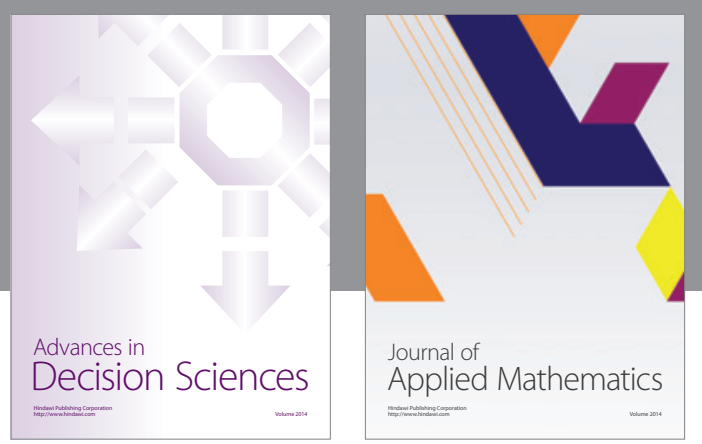

Algebra

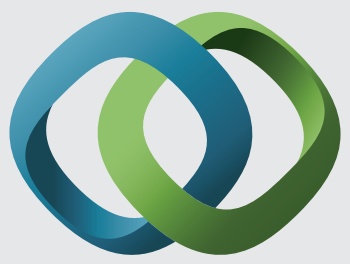

\section{Hindawi}

Submit your manuscripts at

http://www.hindawi.com
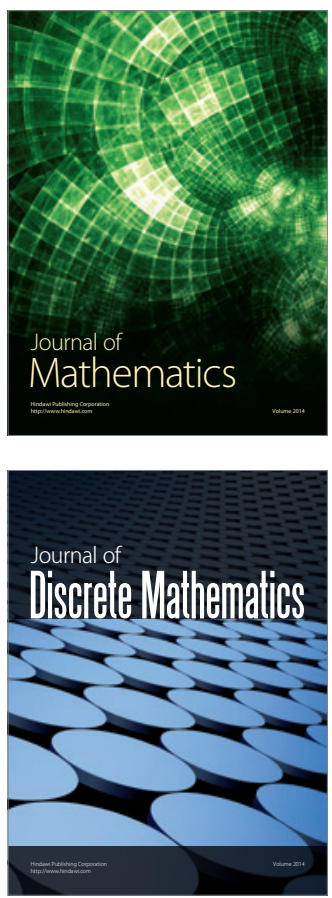

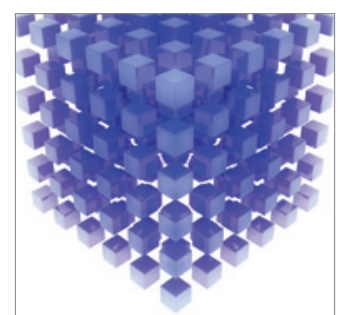

Mathematical Problems in Engineering
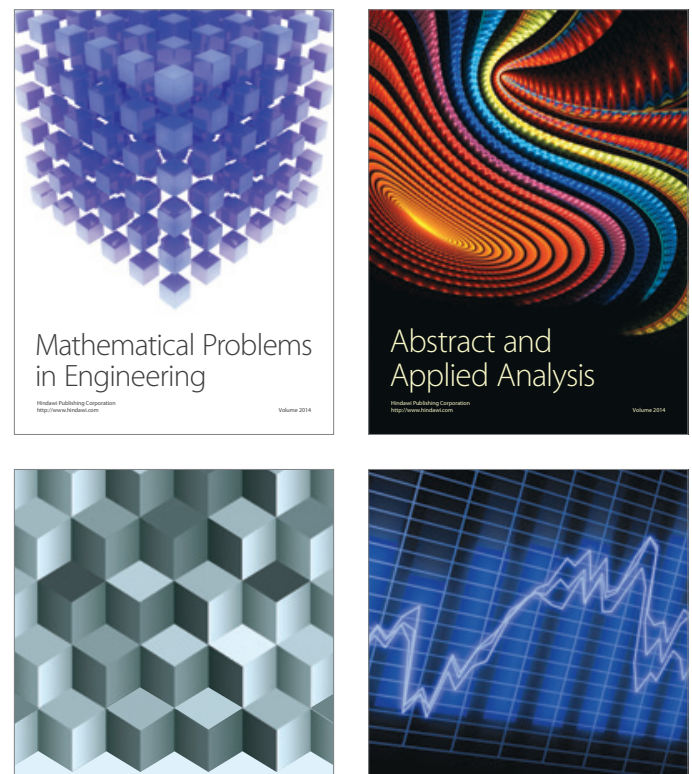

Journal of

Function Spaces

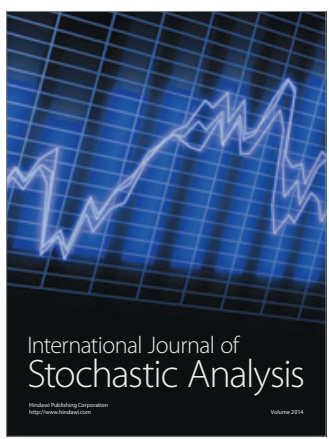

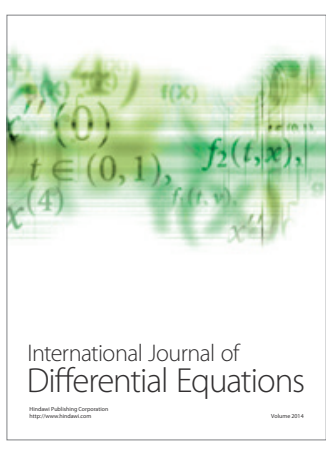
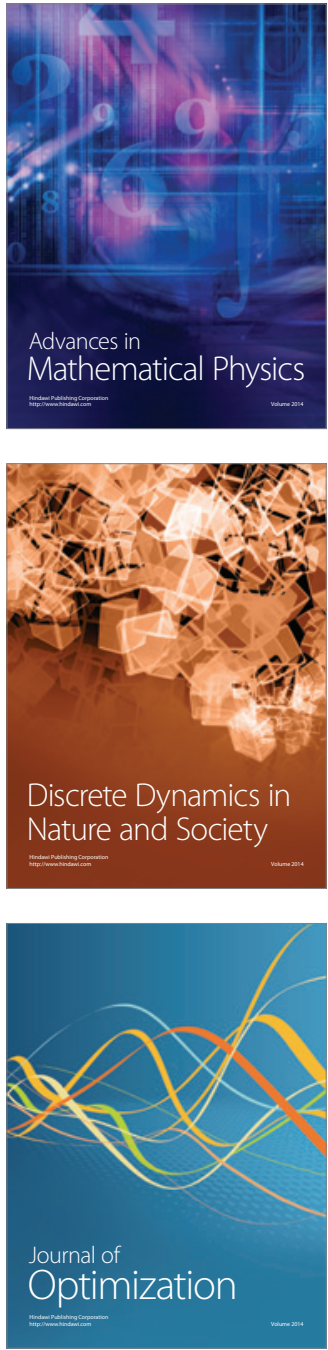